\title{
PENGEMBANGAN MODUL PEMBELAJARAN SENI RUPA TEKNIK TEMPEL BAGI PESERTA DIDIK KELAS IV SEKOLAH DASAR
}

\author{
Probosiwi $^{1}$, Wahyu Andika ${ }^{2}$ \\ ${ }^{1,2}$ Universitas Ahmad Dahlan
}

\begin{abstract}
This study aims to determine the steps to develop and assess the learning module's quality for visual arts and paste techniques for fourth-grade elementary school students. This research method uses methods of research and development $(R \& D) ;$ the model used is the model developed by Sugiyono. The study's subjects were media experts, linguists, material experts, learning experts, and teacher assessments. Data collection techniques in the form of product assessments. From the results of the quality assessment module by media expert gets a value of 98.07 by the category of "very decent", the material experts got a value of 92.64 by the category of "very decent", the learning experts got a value of 78.57 by the category of "worth", linguists get a score of 78.33 with the "feasible" category, the average score obtained from expert validation is 86.90 with the "very feasible" category. The class teacher's responses received an average score of 88.88 in the "very feasible" category. The final result of the assessment from the validation expert and the teacher was obtained with a score of 87.89 in the category of "very feasible" so that it shows that the learning module of the art of sticky technique for grade IV elementary schools is very good to be used as a learning resource for students and teachers.
\end{abstract}

Keywords: Teaching Materials, Learning Module, Fine Arts

\begin{abstract}
Abstrak: Penelitian ini bertujuan untuk mengetahui bagaimana langkah-langkah mengembangkan dan mengatahui kualitas modul pembelajaran seni rupa teknik tempel bagi peserta didik kelas IV sekolah dasar. Metode penelitian ini menggunakan metode research and development (R\&D), model yang digunakan adalah model yang dikembangkan oleh Sugiyono. Subjek penelitian ini adalah ahli media, ahli bahasa, ahli materi, ahli pembelajaran, dan penilaian guru. Teknik pengumpulan data berupa penilaian produk. Dari hasil penilaian kualitas modul oleh ahli media mendapat nilai sebesar 98,07 dengan kategori "sangat layak", ahli materi mendapat nilai sebesar 92,64 dengan kategori "sangat layak", ahli pembelajaran mendapat nilai sebesar 78,57 dengan kategori "layak", ahli bahasa mendapat nilai sebesar 78,33 dengan kategori "layak", didapatkan rata-rata skor dari validasi ahli sebesar 86,90 dengan kategori "sangat layak". Penilaian dari respon guru kelas didapatkan hasil nilai rata-rata sebesar 88,88 dengan kategori "sangat layak". Hasil akhir penilaian dari ahli validasi dan guru didapatkan dengan nilai 87,89 dengan kategori "sangat layak" sehingga hal tersebut menunjukan bahwa modul pembelajaran seni rupa teknik tempel bagi kelas IV sekolah dasar sangat baik digunakan sebagai bahan sumber belajar bagi peserta didik dan guru.
\end{abstract}

Kata Kunci: Bahan Ajar, Modul Pembelajaran, Seni Rupa

\footnotetext{
1 Universitas Ahmad Dahlan Email: siwi.probasiwi国gmail.com

2 Universitas Ahmad Dahlan Email: wahyuandika2802 国gmail.com
} 


\section{PENDAHULUAN}

Dunia pendidikan memerlukan perhatian dalam mencapai tujuan pendidikan yang mencakup media, model, metode maupun sumber bahan ajar yang digunakan untuk menunjang kegiatan pembelajaran sekolah. Guru sebagai pendidik harus memahami komponen pembelajaran yang tepat dalam proses pembelajaran salah satunya memilih bahan ajar. Bahan ajar merupakan salah satu komponen penting dalam menunjang proses pembelajaran. Seperti yang dikemukakan oleh Prastowo (2015, hlm. 17) bahwa bahan ajar dirancang dengan baik untuk menunjukan kompetensi yang harus dikuasi peserta didik dalam proses pembelajaran dengan tujuan untuk perencanaaan dan penelaah implementasi pembelajaran. Bahan ajar disusun secara sistematis guna untuk memberi informasi utuh dari kompetensi yang akan dikuasi oleh peserta didik dalam kegiatan pembelajaran. Bahan ajar mengacu pada kegiatan pembelajaran yang digunakan guru atau peserta didik untuk membantu dalam kegiatan pembelajaran dan meningkatkan pengetahuan atau pengalaman (Emzir, 2012, hlm. 284). Oleh karena itu, penggunaan bahan ajar salah satu hal yang tepat untuk peserta didik agar dapat memberikan kemudahan dalam memahami dan memperlajari materi yang disampaikan oleh guru. Tentu saja bahan ajar yang digunakan harus sesuai dengan kebutuhan peserta didik, efektif dalam pembelajarann efisien dalam penggunaan, serta materi dan tujuan harus selaras dengan karakteristik peserta didik.

Bahan ajar yang sesuai dengan kebutuhan peserta didik adalah modul. Modul pembelajaran merupakan salah satu bahan belajar yang dapat dimanfaatkan oleh peserta didik secara mandiri. Modul yang baik harus disusun sesuai kompenen yang menarik, jelas, dan modul dapat digunakan kapanpun dan dimanapun sesuai dengan kebutuhan peserta didik. Modul merupakan salah satu kompenen dalam pembelajaran dalam bentuk sebuah bahan ajar yang dirancang secara runtut, memiliki komponen pembelajaran dan tujuan pembelajaran dalam membantu peserta didik untuk mempelajari materi, selain itu modul sebagai media sarana dalam pembelajaran yang digunakan guru dan peserta didik, yang memiliki sifat mandiri sehingga peserta didik dapat menggunakan modul tanpa dampingan guru secara mandiri sesuai dengan kempuan belajar yang berbeda-beda (Daryanto, 2013, hlm. 9). Setiap bagian modul terdapat petunjuk penggunaan untuk peserta didik belajar, memahami materi isi pembelajaran hingga soal-soal untuk mengukur kemampuan peserta didik dalam menggunakan modul pembelajaran. Modul pembelajaran memiliki perbedaan dari bahan ajar cetak lainya salah satunya dari segi kegunaan untuk peserta didik dapat belajar secara mandiri, memuat konsep pemahaman pembelajaran yang dapat dipelajari sendiri oleh peserta didik (self instruction), oleh karena itu dalam proses pembelajaran peserta didik dapat aktif belajar (active learning) (Deviana, 2018, hlm. 48).

Banyak orang yang memandang pembelajaran SBdP hanya menggambar, melukis, menyanyi, dan mewarnai padahal pembelajaran yang berkaitan dengan seni dapat menumbuhkan kreativitas peserta didik dalam berkarya. Namun, pembelajaran SBdP di sekolah hanya menggunakan buku tematik yang disediakan oleh sekolah, dalam buku tersebut peserta didik tidak bisa mengeksplorasikan dirinya untuk berkarya sedangkan pembelajaran hanya berpusat di guru. Dalam pembelajaran SBdP di sekolah dasar terdapat salah satu materi seni rupa teknik tempel pada kompetensi dasar kelas IV yaitu pertama 3.4 mengetahui karya seni rupa teknik tempel, kedua 4.4 membuat karya kolase, montase, aplikasi dan mozaik pada materi SBdP kelas IV sekolah dasar. Pitriani (2020, hlm. 71-72) menyatakan bahwa kompetensi yang terdapat dalam materi SBdP pada sekolah dasar mencakup 
$\begin{array}{lccr}\text { beberapa } & \text { kompetensi } & \text { antara lain } \\ \text { kompetensi } & \text { sikap, } & \text { kompetensi } \\ \text { pengetahuan, } & \text { dan } & \text { kompetensi }\end{array}$ keterampilan. Kompetensi dasar tesebut sangat bagus jika dikembangkan sesuai dengan indikator karena pada kompetensi dasar tersebut peserta didik dituntut untuk belajar dan praktik membuat karya seni rupa teknik tempel. Melalui proses karya seni menempel menjadikan salah satu media untuk mengekspresikan anak sesuai kepribadianya dalam mengungkapkan ide melalui karya yang indah (Harni \& Yunisrul, 2018, hlm. 2). Sedangkan menurut (Mega \& Giyartini (2018, hlm. 241-242) bahwa seni rupa merupakan materi pelajaran SBdP yang terdapat di sekolah dasar memiliki tujuan untuk mengapresiasikan sebuah karya seni rupa dan mengekspresikannya melalui karya seni dari pengembangan dasar dan kreativitas.

Pembelajaran seni rupa teknik tempel mencakup dari materi kolase, montase, aplikasi, dan mozaik. Teknik tempel yang menggunakan bahan sederhana untuk menghasilkan karya yang luar biasa. Teknik tempel tersebut dipelajari peserta didik dan guru kelas IV sekolah dasar, namun banyak dari peserta didik tidak dapat membedakan antara karya seni rupa kolase, montase, aplikasi, dan mozaik semuanya mengangap bahwa karya tersebut adalah kolase. Berdasarkan hasil penelitian pada bulan agustus 2019 didapat data $50 \%$ peserta didik tidak mengetahui perbedaan dan pengetahuan mengenai seni rupa teknik tempel.

Hal tersebut mengakibatkan peserta didik kurang aktif dalam pembelajaran seni rupa sehingga hasil belajar peserta didik dari segi pengetahuan dan praktik yang masih rendah berpengaruh terhadap nilai KKM yang telah ditetapkan oleh sekolah. Lisdyanto \& Ary (2018, hlm. 67) menyatakan bahwa buku ajar materi kolase efektif digunakan dalam pembelajaran SBdP materi kolase, yang dibuktikan dengan adanya perbedaan yang signifikan antara hasil uji coba tersebut, bahwa buku ajar dapat meningkatkan hasil belajar siswa yang pada awalnya rata-rata 51,6 menjadi 80,54.

Modul pembelajaran seni rupa teknik tempel dapat melatih perkembangan kognitif dan kemampuan kreatif peserta didik. Agustin et al., (2019, hlm. 312) mengatakan bahwa ketersedian bahan ajar seni rupa yang memiliki kualitas dan menarik agar mendorong peserta didik untuk belajar dengan memperkuat proses pembelajaran sehingga belajar seni rupa lebih menyenangkan dan lebih mudah. Sehingga proses pembelajaran seni teknik tempel (kolase, montase, aplikasi, dan mozaik) merupakan kegiatan bermain dan berseni secara langsung dalam pembelajaran (Harni \& Yunisrul, 2018, hlm. 1). Dengan menyusun dan menempel satu persatu bahan yang digunakan dalam pembelajaran seni rupa teknik tempel.

Berdasakan uraian permasalahan tersebut peneliti mencoba mengembangkan suatu bahan ajar berupa modul pembelajaran seni rupa teknik tempel bagi peserta didik kelas IV Sekolah Dasar dengan tujuan untuk memberikan sumber belajar pada seni rupa khususnya seni teknik tempel (kolase, montase, aplikasi, dan mozaik). (Rakhmadina \& Suprayitno, 2020, hlm. 408) pembelajaran pada materi SBdP karya seni rupa teknik tempel belum terfokus dan masih rancu antara materi kolase, montase, aplikasi, dan mozaik. Sehingga dibutuhkan bahan ajar modul pembelajaran yang memuat dan mencakup materi seni rupa teknik tempel dari unsur-unsur seni rupa sampai materi dan langkah-langkah praktek membuat karya seni rupa teknik tempel yang termuat pada modul pembelajaran tersebut.

\section{METODOLOGI PENELITIAN}

Model pengembangan yang digunakan dalam penelitian ini merupakan penelitian dan pengembangan (Research and Development). Penelitian ini merupakan salah satu metode penelitian yang diinginkan untuk menghasilkan produk tertentu dan menguji keefektifan 
produk yang dihasilakan (Sugiyono, 2017, hlm. 297). Langkah-langkah yang dituliskan oleh Sugiyono terdiri dari beberapa tahapan yaitu: potensi dan masalah, mengumpulkan informasi, desain produk, validasi desain, revisi desain, uji coba produk, revisi produk, ujicoba pemakaian, revisi produk, dan produk massal (Sugiyono, 2015, hlm. 409-426).

Prosedur penelitian pengembang yang dilakukan adalah penelitian dan pengembangan atau R\&D. Menurut (Sugiyono, 2019, hlm. 30). penelitian dan pengembangan atau dalam bahasa Inggrisnya Research and Development dapat diartikan sebagai cara ilmiah untuk, meneliti, merancang, memproduksi dan menguji validitas produk yang telah dihasilkan. Menurut Borg and Gall penelitian dan pengembangan (R\&D) ada sepuluh langkah-langkah dan pengembangan secara rinci sebagai berikut.

1. Potensi dan Masalah: langkah pertama dalam penelitian ini dimulai dari menganalisis potensi dan masalah yang ada di sekolah dasar yaitu melakukan observasi ke sekolah. Hal tersebut dilakukan untuk mengetahui perlu atau tidaknya media jika dikembangkan untuk menunjang proses pembelajaran yang digunakan peserta didik dan guru.

2. Pengumpulan Data: analisis kurikulum untuk menentukan materi pembelajaran yang akan digunakan dalam pengembangan media berbasis seni rupa. Penelitian ini menggunakan Kurikulum 2013). Sedangkan, studi literatur dilakukan untuk mengkaji hasil pengumpulan data dari sumber observasi, wawancara, buku, jurnal, dan prosiding.

3. Desain Produk: menyusun desain dan mengembangkan media modul pembelajaran seni rupa. Media tersebut didesain sedemikian rupa guna tercapainya suatu media yang diharapkan. Hal pertama yang dilakukan adalah merancang desain media dengan menggunakan Corel
Draw X7 sesuai dengan spesifikasi media pembelajaran antara lain: a) Sampul modul menggunakan kertas ivory 250 gr berwarna dan tampilan yang menarik. Isi modul menggunakan kertas HVS 70 gr; b) Isi modul pembelajaran seni rupa teknik tempel ini membahas tentang materi pada buku tematik mata pelajaran SBdP yang mencakup kompetensi dasar 3.4 mengetahui karya seni rupa teknik tempel, 4.4 membuat karya kolase, montase, aplikasi dan mozaik di materi SBdP kelas 4 sekolah dasar, pokok bahasan, indikator pencapaian, lembar kegiatan pembelajaran dan soal evaluasi; c) Memiliki peta konsep materi yang akan dibahas; d) Terdapat petunjuk penggunaan bagi guru dan peserta didik pada halaman depan.

4. Validasi Desain: validasi desain dilakukan bertujuan untuk mengetahui kualitas modul pembelajaran yang telah dikembangkan serta untuk menggali masukan maupun saran terhadap media yang dikembangkan, sehingga dilakukan perbaikan desain supaya produk yang dihasilkan menjadi lebih baik. Validasi desain produk dilakukan oleh 4 pakar ahli (ahli media, ahli materi, ahli pembelajaran, dan ahli bahasa).

5. Revisi Desain: langkah selanjutnya adalah perbaikan desain atau revisi desain. Modul pembelajaran yang telah divalidasi oleh 4 pakar ahli kemudian direvisi sesuai dengan saran serta masukan yang telah diberikan oleh keempat ahli tersebut. Perbaikan desain ini dimaksudkan untuk memperoleh produk yang lebih baik sehingga dapat di ujicobakan dalam proses pembelajaran.

6. Uji Coba Produk: langkah selanjutnya adalah uji coba produk. Dalam langkah ini, penulis mengujicobakan produk modul pembelajaran ke dalam proses pembelajaran materi SBdP. Modul pembelajaran seni rupa teknik tempel diujicobakan ke guru untuk mengetahui 
penilaian respon guru terhadap modul pemeblajaran. Uji coba melibatkan dua guru kelas IVA dan IVB.

7. Revisi Produk: selanjutnya setelah uji coba produk dilakukan, langkah ke tujuh adalah revisi produk. Revisi produk didapatkan dari saran ataupun masukan dari guru dan peserta didik saat mengamati modul pembelajaran seni rupa teknik tempel.

Uji coba pada produk modul pembelajaran seni rupa teknik tempel bermaksud untuk mengumpulkan data-data yang dibutuhkan dalam pengembangan produk. Pada tahap uji coba ini terdapat beberapa hal yang perlu dikembangkan yaitu acuan atau tolok ukur dalam menentukan kelayakan dari produk yang telah dikembangkan sebagai berikut.

\section{a) Desain Uji Coba}

Desain Uji coba dilakukan untuk memperoleh data yang akan digunakan sebagai dasar untuk menyempurnakan modul pembelajaran seni rupa teknik tempel yang telah dibuat dengan mempraktum secara langsung di lapangan. Adapun tahap-tahap uji coba dalam penelitian ini, yaitu sebagai berikut: (1) uji coba oleh ahli dilakukan untuk mengetahui kualitas media yang telah dikembangkan. Tahap uji coba atau validasi dilakukan oleh 4 pakar ahli, yaitu ahli media, ahli materi, ahli pembelajaran dan ahli bahasa. Uji ahli ini dilakukan oleh dosen PGSD di Universitas Ahmad Dahlan yang ahli dalam bidangnya untuk memberikan penilaian produk awal, serta memberikan saran atau masukan untuk perbaikan produk; (2) uji coba produk dilakukan setelah mendapatkan validasi dari ahli dapat dijadikan dasar untuk merevisi produk selanjutnya melakukan uji coba produk. Uji coba produk dilakukan untuk mengetahui penilain respon guru terhadap modul pembelajaran seni rupa teknik tempel yang melibatkan guru kelas IV SD Muhammadiyah Macanan. Guru diminta membaca modul pembelajaran tersebut kemudia mengisi penilaian respon guru terhadap modul pembelajaran tersebut.

\section{b) Subjek Coba}

Subjek coba dilakukan juga ke para ahli media, ahli materi, ahli pembelajaran dan ahli bahasa. Selain itu, uji coba dilakukan kepada guru kelas untuk mengetahui respon dan penilaiannya terhadap produk dan kelayakan sebagai media pembelajaran.

\section{c) Jenis Data}

Jenis data yang digunakan dalam penelitian pengembangan ini adalah data kualitatif dan kuantitatif. Data kualitatif berupa tanggapan, saran, serta masukan dari penguji ahli terhadap media yang dikembangkan, kemudian dari hasil saran dan tanggapan terhadap guru. Data kuantitatif diperoleh dari angket yang diisi oleh ahli (media, materi, pembelajaran dan bahasa) saat melakukan validasi media modul pembelajaran seni rupa. Data kuantitatif ini berupa penilaian terhadap pengembangan media modul pembelajaran berbasis seni rupa.

Seluruh data kualitatif dan data kuantitatif yang diperoleh dari penilaian penguji ahli media, ahli materi, ahli pembelajaran, ahli bahasa, digunakan untuk merevisi seluruh komponen media modul pembelajaran berbasis seni rupa yang diujicobakan agar mendapatkan media yang layak dan efektif digunakan dalam proses pembelajaran materi mitigasi bencana.

\section{Instrumen Pengumpulan Data}

Instrumen pengumpulan data adalah alat bantu yang dipilih dan digunakan oleh peneliti dalam kegiatan mengumpulkan agar kegiatan tersebut menjadi sistematis dan dipermudah olehnya. Peneliti dapat menggunakan beberapa cara untuk mengumpulkan data diantaranya, angket (questionnaire), wawancara (interview), pengamatan (observation), tes (test) dan lain sebagainya (Arikunto, 2011, hlm. 101). Dalam penelitian pengembangan yang dilakukan oleh peneliti ini menggunakan instrumen untuk mengumpulkan data oleh peneliti adalah 
pengamatan, wawancara, lembar penilaian, angket respon guru dan angket respon peserta didik.

a. Lembar Pengamatan: dilakukan untuk pengamatan yang dilakukan secara langsung. Kegiatan pengamatan yang dilakukan oleh penelitian adalah kegiatan pengamatan aktivitas peserta didik kelas 4 sekolah dasar pada saat di sekolah secara langsung.

b. Lembar Wawancara: digunakan sebagai teknik pengumpulan data apabila peneliti melakukan studi pendahuluan untuk menemukan permasalahan dan potensi yang harus diteliti. Teknik pengumpulan data ini didasarkan dari laporan tentang diri sendiri, setidak-tidaknya pada pengetahuan atau keyakinan pribadi (Sugiyono, 2019, hlm. 231). Peneliti dalam mengumpulkan data dengan wawancara kepada guru kelas 4 sekolah dasar untuk memperoleh informasi terkait masalah dalam pembelajaran di sekolah.

c. Lembar Penilaian: sebagai salah satu teknik pengumpulan data yang dilakukan peneliti untuk mengetahui hasil dari penilian media pembelajar kemudian menganalisis data pada lembar penilaian agar peneliti mengetahui kelayakan dan kualitas modul pembelajaran berbasis seni rupa. Penilaian adalah proses pengumpulan berbagai data yang bisa memberikan gambaran perkembangan belajar siswa (Kunandar, 2019, hlm. 231). Penilaian adalah rangkaian kegiatan untuk memperoleh, menganalisis, dan menafsirkan data tentang proses dan hasil belajar peserta didik yang dilakukan secara sistemastis dan berkesinambungan, sehingga dapat menjadi informasi yang bermakna dalam pengambilan keputusan (Kunandar, 2019, hlm. 111). Berdasarkan pendapat dari atas maka penilain sangat dibutuhkan untuk memperoleh hasil dan mengetahui kekurangan terutama dalam pengembangan media modul pembelajaran berbasis seni rupa. Kemudian lembar penilaian bertujuan untuk menilai kualitas modul tersebut. lembar penilaian ini meliputi enam jenis penilaian yang disesuaikan dengan responden dari peneliti. Hasil ini digunakan untuk pedoman dari revisi produk media yang dikembangkan.

Teknik analisis data yaitu diarahkan untuk menjawab rumusan masalah atau menguji hipotesis yang telah dirumuskan dalam penelitian (Sugiyono, 2017, hlm. 333). Pada penelitian pengembangan ini ada dua, yaitu teknik analisis data kualitatif dan teknik analisis data kuantitatif. Teknik analisis ini untuk mengolah data dari penilaian yang terkumpul kemudian dianalis. Kedua teknik analisis data tersebut akan dijelaskan sebagai berikut.

a. Teknik Analisis Data Kualitatif: diperoleh dari tanggapan, komentar, serta saran dari lembar penilaian ahli (ahli media, ahli materi, ahli pembelajaran, dan ahli bahasa), lembar pengamatan, wawancara, lembar respon guru kelas IV.

b. Teknik Analisis Data Kuantitatif: diperoleh dari hasil uji kelayakan produk subjek validasi ahli seperti ahli media, ahli materi, ahli pemebelajaran, ahli bahasa yaitu dosen, penilaian dari guru kelas IV. Analisis dilakukan dengan cara menghitung seluruh penilaian yang dilakukan oleh para penilai dan dapat diukur dengan menggunakan skala Likert untuk para ahli dan guru.

Proses menganalisis data yang berasal dari angket bergradasi 4, maka alternatifnya ditentukan sebagai berikut: (1) "Sangat banyak", "Sangat sering", "Sangat setuju", dan lain-lain menunjukkan gradasi paling tinggi; (2) "Banyak", "Sering", "Kurang setuju", dan lain-lain, menunjukkan peringkat yang lebih rendah dibandingkan dengan yang ditambah kata "Sangat". Oleh karena itu, kondisi tersebut diberi nilai 3; (3) 
"Sedikit", "Jarang", "Kurang setuju", dan lain-lain, karena berada di bawah "Setuju" dan sebagainya, diberi nilai 2; (4) "Sangat sedikit" dan "Sedikit sekali", "Sangat jarang", "Sangat kurang setuju", yang berada di gradasi paling bawah, diberi nilai 1 (Arikunto, 2013, hlm. 285).

\section{HASIL PENELITIAN DAN PEMBAHASAN}

Berdasarkan hasil penelitian bahwa pembelajaran di SD Muhammadiyah Macanan dalam proses belajar-mengajar Seni, Budaya, dan Prakarya (SBdP) ditemukan bahwa guru tidak memiliki buku pendamping lain selain buku paket tematik, peserta didik kurang memahami perbedaan seni teknik tempel kolase, montase, aplikasi dan mozaik, sehingga pembelajaran SBdP tersebut kurang menarik. Maka peneliti mengembangan modul pembelajaran seni rupa teknik tempel sebagai bahan rujukan bagi guru dan peserta didik.

Penelitian ini mengembangkan modul pembelajaran seni rupa teknik tempel bagi peserta didik kelas IV sekolah dasar pada materi SBdP. Modul tersebut digunakan sebagai bahan ajar guru dan peserta didik yang telah melalui tahap validasi ahli dan respon penilaian guru. Berikut ini adalah gambar modul pembelajaran seni rupa teknik tempel:

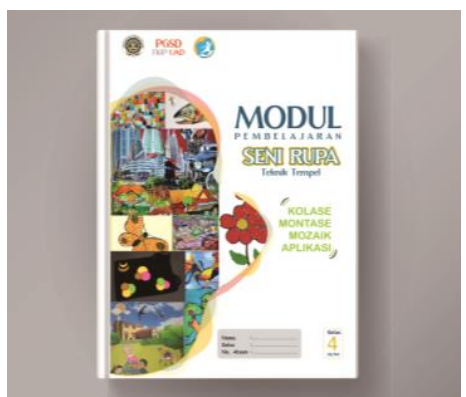

Gambar 1. Modul pembelajaran seni rupa teknik tempel

(Sumber foto: Wahyu Andika, 2020)

Prosedur penelitian pengembangan modul pembelajaran seni rupa teknik tempel melalui 7 tahap, yaitu: potensi dan masalah adalah pengumpulan informasi meliputi observasi dan pengamatan langsung di sekolah dasar, selanjutnya tahap pengumpulan data yaitu analisis kebutuhan dan analisis kurikulum. Analisis kebutuhan menggali informasi melalui peserta didik dan guru saat pembelajaran, analisis kurikulum melakukan pengembangan modul sesuai dengan kurikulum 2013 pada kompetensi dasar 3.4 mengetahui karya seni rupa teknik tempel, 4.4 membuat karya kolase, montase, aplikasi dan mozaik pada materi SBdP kelas IV sekolah dasar.

Tahap berikutnya yaitu desain produk diawali dengan membuat konsep desain produk modul pembelajaran meliputi halaman cover modul, halaman identitas, kata pengantar, daftar isi, KI KD dan indikator, peta konsep, petunjuk penggunan, pendahuluan materi, materi isi (materi dan praktik pembelajaran) dilengkapi dengan contoh vidio dalam membuat karya seni tersebut, soal evaluasi, rangkuman, daftar pustaka, dan identitas penyusun. Desain pengembangan modul seni rupa teknik tempel ini menggunakan aplikasi Corel Draw dan memberikan nuansan ceria dengan memunculkan warna-warna salah satu unsur seni rupa dan sesuai karakteristik peserta didik sekolah dasar.

Berikutnya tahap validasi desain dengan cara melakukan validasi kepada validasi ahli. Validasi ahli yaitu ahli media, ahli pembelajaran, ahli materi, dan ahli bahasa. Tahap validasi ini bertujuan untuk mengetahui penilaian para ahli terhadap media yang dikembangkan oleh peneliti.

Sebelum melakukan validasi ke ahli, peneliti melakukan validasi instrumen kepada ahli validasi instrumen yang akan di setujui. Kemudian para ahli melakukan validasi modul pembelajaran seni rupa teknik tempel melalui instrumen penilaian yang telah di setujui oleh validator instrumen. Instrumen penilaian disajikan dalam bentuk data kualitatif yang berisi pertanyaan yang menurut ahli teori kemudian dikembangkan oleh peneliti. 
Adapun hasil penilaian yang dilakukan oleh validasi sebagai berikut:

Tabel 1. Hasil Penilaian oleh Validasi Ahli

\begin{tabular}{lc}
\hline Validasi Ahli & Nilai \\
\hline Ahli Media & 98,07 \\
\hline Ahli Materi & 92,64 \\
\hline Ahli Pembelajaran & 78,57 \\
\hline Ahli bahasa & 78,33 \\
\hline Jumlah Nilai & $\mathbf{3 4 7 , 6 1}$ \\
\hline Rata-rata & $\mathbf{8 6 , 9 0}$ \\
\hline Kategori & Sangat Layak \\
\hline
\end{tabular}

Berdasarkan tabel di atas, bahwa hasil penilaian yang telah dilakukan oleh validasi ahli media, ahli materi, ahli pembelajaran, dan ahli bahasa mendapatkan nilai rata-rata 86,90 sehingga modul pembelajaran seni rupa teknik tempel dikatakan dalam kategori "sangat layak". Maka dapat ditarik kesimpulan dari hasil penilaian oleh validasi ahli yaitu modul pembelajaran sangat layak digunakan dalam proses pembelajaran.

Selain memberikan penilaian, ahli juga memberikan masukan saran dan komentar yaitu:

a) Ahli media: memberikan masukan mengenai tata tulisan desain di bagian sampul belakang. Selebihnya sudah bagus dan menarik.

b) Ahli materi: masukan gambar dengan resolusi yang tinggi, sumber atau rujukan dilengkapi pada bagian pembahasan. Penjabaran materi agar pembaca paham dengan maksud dan tujuan tersebut.

c) Ahli Pembelajaran: poin di RPP materi dituliskan garis besar materi yang akan dibahas; pada kegiatan pembelajaran atau inti belum terlihat fase-fase strategi yang digunakan oleh penulis; kunci jawaban dilampirkan pada soal evaluasi yang terdapat pada modul ke RPP.

d) Ahli Bahasa: Pedoman Umum Ejaan Bahasa Indonesia digunakan, misalnya penggunaan tanda baca diteks tersebut masih banyak yang tidak tepat; aplikasi KBBI offline diunduh untuk mengecek kebakuan kata; penggunaan kata asing harus miring.

Masukan saran dan komentar oleh para validasi ahli berguna untuk memperbaiki modul pembelajaran seni rupa teknik tempel untuk mencapai kualitas kelayakan modul pembelajaran tersebut. Selanjutnya tahap uji coba ke peserta didik. Namun, proses uji coba produk tidak dapat terlaksana dikarenakan adanya wabah pandemi Covid-19 yang menyebabkan sekolah harus libur selama waktu yang tidak dapat ditentukan. Oleh karena itu, uji coba produk modul pembelajaran seni rupa teknik tempel untuk kelas IV sekolah dasar tidak dapat terlaksana.

Maka hal tersebut menyebabkan peneliti kekurangan data dari hasil uji coba produk terhadap peserta didik. Akan tetapi, modul pembelajaran seni rupa teknik tempel dapat dinilai oleh guru wali kelas IV/A dan IV/B SD Muhammadiyah Macanan. Tujuan penilaian oleh guru terhadap modul pembelajaran seni rupa teknik tempel untuk respon penilaian guru, kemudian mengetahui masukan saran dan komentar guru terhadap modul tersebut sebagai pendidik yang mengetahui proses pembelajaran di kelas. Adapun hasil penilaian respon yang dilakukan oleh guru wali kelas IVA dan B sebagai berikut:

Tabel 2. Hasil Penilaian Respon Guru

\begin{tabular}{lc}
\hline Respon Guru & Nilai \\
\hline Penilaian Guru IV/A & 94,44 \\
\hline Penilaian Guru IV/B & 83,33 \\
\hline Jumlah Nilai & $\mathbf{1 7 7 , 7 7}$ \\
\hline Rata-rata & $\mathbf{8 8 , 8 8}$ \\
\hline Kategori & Sangat Layak \\
\hline
\end{tabular}

Berdasarkan tabel di atas, bahwa hasil penilaian yang telah dilakukan oleh guru dari aspek materi, media, pembelajaran dan bahasa mendapatkan nilai rata-rata 88,88 sehingga modul pembelajaran seni rupa teknik tempel dikatakan dalam kategori "sangat layak". Maka dapat disimpulkan dari hasil penilaian keseluruhan yaitu modul 
pembelajaran sangat layak digunakan dalam proses pembelajaran

Guru juga memberikan masukan saran dan komentar terhadap modul pembelajaran, yaitu:

a) "Modul pembelajaran sudah sesuai dengan materi SBdP yang diajarkan kelas IV terkait materi karya seni rupa tempel", berdasarkan komentar tersebut dapat diketahui bawah modul pembelajaran seni rupa teknik tempel sudah sesuai dengan materi SBdP untuk kelas IV.

b) "Dengan adanya modul ini pembelajaran materi dan mengaplikasikannya dalam praktik SBdP terurtama seni rupa teknik tempel membantu saat proses belajar mengajar agar peserta didik dapat mencapai kompetensi dan tujuan yang diharapakan", berdasarkan komentar tersebut dapat diketahui bawah modul pembelajaran seni rupa teknik tempel sudah sesuai dengan apa yang diingikan oleh guru agar membantu peserta didik dalam proses pembelajaran.

Berdasarkan keseluruhan penilaian kelayakan produk dari ahli media, ahli materi, ahli pembelajaran, ahli bahasa, dan guru wali kelas diakumulasikan nilai yang selanjutnya dihitung rata-rata. Hasil akumulasi penilaian kelayakan produk dapat dilihat dalam bentuk tabel berikut.

Tabel 3. Data Hasil Penilaian Kelayakan Produk

\begin{tabular}{lc}
\hline Penilaian & Nilai \\
\hline Validasi Ahli & $\mathbf{8 6 , 9 0}$ \\
\hline Penilaian Guru & $\mathbf{8 8 , 8 8}$ \\
\hline Jumlah Nilai & $\mathbf{1 7 5 , 7 8}$ \\
\hline Rata-rata & $\mathbf{8 7 , 8 9}$ \\
\hline Kategori & Sangat Layak \\
\hline
\end{tabular}

Berdasarkan tabel di atas, dapat diketahui hasil penilaian terhadap modul pembelajaran seni rupa teknik tempel untuk kelas IV sekolah dasar diperoleh jumlah nilai 175,78 dan jumlah rata-rata 87,89. Hasil nilai tersebut menunjukan bahwa Modul Pembelajaran Seni Rupa
Teknik Tempel memperoleh kategori "sangat layak".

Hasil dari penilaian yang telah dijabarkan dapat diketahui bahwa pembelajaran SBdP diperlukan menggunakan modul karena dapat digunakan sebagai media pembelajaran mandiri, sehingga peserta didik dapat memanfaatkan modul meskipun tanpa ada kehadiran guru di kelas (Artyanto, 2013, hlm. 7). Pembelajaran seni rupa teknik tempel memerlukan rujukan sumber lain seperti modul untuk mengembangkan kreaktifitas peserta didik dalam berkarya seni. Agar wawasan peserta didik dan guru terfokus dalam materi pembelajaran seni rupa teknik tempel.

\section{KESIMPULAN}

Penelitian ini mengembangkan bahan ajar modul pembelajaran seni rupa teknik tempel bagi peserta didik kelas IV SD menggunakan model pengembangan dan penelitian yang dikembangkan oleh Sugiyono yang terdiri dari pertama melakukan pengamatan potensi dan masalah dengan observasi secara langsung di sekolahan, mengumpulkan informasi lalu menganalisis kebutuhan untuk potensi masalah tersebut, tahap selanjutnya melakukan desain produk dengan merancang desain dan mengembangkan materi pada modul. Kemudian validasi desain modul ke para ahli (media. Materi, pembelajaran dan bahasa), hasil dari validasi yaitu hasil penilaian dan perbaikan desain. Setelah itu uji coba produk ke peserta didik yang tidak dapat dilakukan dikarenakan pademi Covid-19 oleh karena itu, peneliti hanya melakukan penilaian modul terhadap guru kelas, selanjutnya tahap revisi produk dari saran dan komentar oleh guru.

Pengembangan

modul pembelajaran seni rupa teknik tempel bagi peserta didik kelas IV sekolah dasar berdasarkan hasil penilaian dari ahli media mendapatkan nilai 98,07 dengan kategori "sangat layak" dan layak digunakan kriteria bahan ajar. Hasil validasi ahli 
materi memperoleh nilai 92,64 dengan kategori "sangat layak" sesuai dengan KD dan Indikator materi. Hasil penilaian validasi ahli pembelajaran diperoleh nilai 78,57 dengan kategori "layak" bahwa modul sesuai dengan syarat pembelajaran. Penilaian dari ahli bahasa medapatkan nilai 78,33 dengan kategori "layak" sesuai dengan kelayakan bahasa yang digunakan. Hasil penilaian rata-rata oleh guru memperoleh nilai 88,88 dan masuk dalam kategori "sangat layak".

Berdasarkan rata-rata hasil penilaian uji validasi dan penilaian guru diperoleh hasil akumulasi kelayakan produk sebesar 175,78 dengan nilai ratarata 87,89 masuk dalam kategori "Sangat Layak". Berdasarkan hasil dari data tersebut dapat dinyatakan bahwa pengembangan modul pembelajaran seni rupa teknik tempel bagi peserta didik kelas IV sekolah dasar sangat layak digunakan untuk kegiatan pembelajaran.

\section{DAFTAR PUSTAKA}

Agustin, T., Sumbawati, M. S., \& Sitompul, N. C. (2019). Pengembangan Bahan Ajar Seni Budaya ( Seni Rupa ) Kelas VII di SMP Negeri 4 Surabaya. Jurnal Education and Development Institut, 7(3), 312-317.

Arikunto, S. (2011). Prosedur Penelitian: Suatu Pendekatan Praktik Edisi Revisi VII. PT. Rineka Cipta.

Arikunto, S. (2013). Dasar-dasar Evaluasi Pendidikan. Bumi Aksara.

Artyanto. (2013). Pengembangan Modul Seni Budaya dan Ketrampilan "Apresiasi Karya Seni Rupa" Untuk Meningkatkan Prestasi Belajar Siswa Kelas IV di SDN Babat VI BabatLamongan. Jurnal Mahasiswa Teknologi Pendidikan, 01(01), 01-09.

Daryanto. (2013). Menyusun Modul Bahan Ajar Untuk Persiapan Guru dalam Mengajar. Gava Media.

Deviana, T. (2018). Analisis Kebutuhan Pengembangan Kabupaten Tulungagung Untuk Kelas V Sd.
Jurnal Pemikiran Dan

Pengembangan SD, 6(20), 47-56.

Emzir. (2012). Metodologi Penelitian Pendidikan Kuantitatif dan Kualitatif. Rajagrafindo Persada.

Harni \& Yunisrul. (2018). Pelatihan ketrampilan berkarya seni kolase, mozaik, dan montase untuk guru sd. $1-5$.

Kunandar. (2019). Penilaian Autentik (Penilaian Hasil Belajar Peserta Didik Berdasarkan Kurikulum 2013). Rajawali Pres.

Lisdyanto, N. D., \& Ary, D. da. (2018). Pengembangan Buku Ajar Materi Kolase Pada Pembelajaran SBDP Kelas IV. Journal of Economic Education, 7(1), 62-68.

Mega, R., \& Giyartini, R. (2018). Pedadidaktika: Jurnal Ilmiah Pendidikan Guru Sekolah Dasar Pengaruh Metode Outdoor Learning terhadap Pembentukan Kreativitas siswa dalam pembelajaran SBdP. 5(4), 240-249.

Pitriani, S. (2020). Analisis Materi Pokok Seni Budaya Dan Prakarya ( SBdP ) Kelas III Mi / SD Analysis of the Subject Matter of Art And Culture at the Third Grade of Elementary School. 7(1), 60-73.

Prastowo. (2015). Panduan Kreatif Mmbuat Bahan Ajar Inovatif. DIVA press.

Rakhmadina, N. L., \& Suprayitno. (2020). Pengembangan bahan ajar handout materi karya seni kolase berbasis bahan alam untuk kelas IV SD. Jurnal Penelitian Pendidikan Guru Sekolah Dasar, 8(2), 407-417.

Sugiyono. (2015). Metode Penelitian Kombinasi (Mix Methods). Alfabeta.

Sugiyono. (2017). Metode Penelitian Kualitatif, Kuantitatif dan $R \& D$. Alfabeta.

Sugiyono. (2019). Metode Penelitian dan Pengembangan (Research and Development $R \& D$. Alfabeta. 